Tropical Journal of Pharmaceutical Research October 2017; 16 (10): 2403-2410

ISSN: $1596-5996$ (print); 1596-9827 (electronic)

(C) Pharmacotherapy Group, Faculty of Pharmacy, University of Benin, Benin City, 300001 Nigeria. All rights reserved.

Available online at http://www.tjpr.org

Original Research Article

http://dx.doi.org/10.4314/tjpr.v16i10.13

\title{
In vivo anti-inflammatory activity of Liquidambar formosana Hance infructescence extract
}

\author{
Haoran Ma, Fuqian Wang, Jie Jiang, Lu Cheng, Hong Zhang* and Geng Zhang \\ Department of Pharmacy, Wuhan First Hospital, Wuhan 430022, Hubei, PR China
}

*For correspondence: Email: wyzh688@126.com; zhanggen888@126.com; Tel: (+86) 27 85332416, 27-85332089

Sent for review: 12 September 2016

Revised accepted: 6 September 2017

\begin{abstract}
Purpose: To evaluate the anti-inflammatory activity of Liquidambar formosana Hance infructescence (Liquidambaris fructus, ELF) in vivo, and clarify its underlying mechanisms.

Methods: The in vivo anti-inflammatory activity of ELF was examined by xylene-induced ear swelling test in mice as well as carrageenan-induced paw edema method in rats. The levels of inflammatory cytokines (TNF- $\alpha, I L-1 \beta, I L-6$ and IL-10) in serum were measured by enzyme-linked immunosorbent assay (ELISA), while the expressions of COX-2, iNOS and NF-KB p65 in paw tissue of rats were evaluated by western blot.

Results: After ELF treatment, the levels of TNF- $\alpha(p<0.001), I L-1 \beta(p<0.001)$ and IL-6 $(p<0.001)$ in serum decreased and the levels of anti-inflammatory cytokine $\mathrm{L}-10$ increased $(p<0.01)$. In addition, ELF treatment resulted in decrease of COX-2 $(p<0.01)$, iNOS $(p<0.01)$ and NF-KB p65 $(p<0.01)$ expressions in Wistar rats.

Conclusion: The results reveal that ELF possesses significant anti-inflammatory effect in vivo. The anti-inflammatory activity is associated with the levels of TNF- $\alpha, I L-1 \beta, I L-6$ and IL-10 in serum. Furthermore, the suppression of NF-KB p65, iNOS and COX-2 is linked to its anti-inflammatory effect. These results provide a rationale for the use of Liquidambaris fructus in inflammatory disease in traditional medicine.
\end{abstract}

Keywords: Anti-inflammatory activity, Liquidambaris fructus, Cytokines, Ear swelling test, Paw edema

Tropical Journal of Pharmaceutical Research is indexed by Science Citation Index (SciSearch), Scopus, International Pharmaceutical Abstract, Chemical Abstracts, Embase, Index Copernicus, EBSCO, African Index Medicus, JournalSeek, Journal Citation Reports/Science Edition, Directory of Open Access Journals (DOAJ), African Journal Online, Bioline International, Open-J-Gate and Pharmacy Abstracts

\section{INTRODUCTION}

As is well-known that inflammation is part of the complex biological response of body tissues to harmful stimuli. The function of inflammation is to eliminate invading pathogens and to initiate healing process, but while it is uncontrolled, over production of inflammatory mediators can lead to cellular injury and may even result in several diseases [1, 2]. During inflammatory process, inflammatory mediators such as NO, PGE2, TNF- $\alpha, \quad I L-1 \beta, \quad I L-6$ and COX-2 are highly produced, all of which have been implicated in the pathogenesis of tissue injury [3].
Non-steroidal anti-inflammatory drugs (NSAIDs) are usually used for the treatment of inflammatory diseases. However, numerous side effects, such as gastrointestinal disorders, immunodeficiency and nephrotoxicity limited the wide use of these drugs [4]. Traditional Chinese medicine may be another choice for the treatment of inflammatory diseases.

Liquidambar formosana Hance belongs to the family Hamamelidaceae. The infructescence of Liquidambar formosana Hance, named Liquidambaris fructus (Lulutong in Chinese), has 
long been used to treat rheumatism and inflammatory diseases in traditional Chinese medicine [5]. But so far, few reports on the antiinflammatory activities of Liquidambaris fructus have been published.

In our study, we administered ELF in vivo and found that ELF has anti-inflammatory effect. This study may contribute to find the pharmacological basis of the use of Liquidambaris fructus in traditional Chinese medicine to treat rheumatism and inflammatory diseases.

\section{EXPERIMENTAL}

\section{Animals}

Male Balb/c mice (18 $22 \mathrm{~g}$ weight) and Wistar rats $(180 \sim 220 \mathrm{~g}$ weight) were purchased from the Center for Disease Prevention and Control in Hubei province, China (no. SCXK (Hubei) 20080005). Animals were housed in plastic cages, maintained at $22 \pm 2{ }^{\circ} \mathrm{C}$ and $45 \sim 65 \%$ humidity with alternating $12 \mathrm{~h}$ light-dark cycle and given free access to both food (standard rat chow) and water. They were bred for 1 week to adapt to the environment before the experiments.

All experiments were approved by the Committee on the Ethics of Animal Experiments of Wuhan First Hospital (no. WHYY14021) and followed the guidelines of 'Principles of Laboratory Animal Care' (World Health Organization (WHO) Chronicle, 1985) [6].

\section{Plant materials}

The infructescence of Liquidambar formosana Hance was purchased from Hubei Tianji Chinese Herbal Medicine Co., Ltd (China), authenticated by Prof Changgong Zhang (Tongji Medical College, Huazhong University of Science and Technology, Wuhan, China) according to Chinese Pharmacopoeia [5]. A voucher specimen (no. L. $f$ 2013-0621) have been deposited in Department of Pharmacy, Wuhan First Hospital, Wuhan, Hubei, PR China.

\section{Chemicals}

Carrageenan and indomethacin were purchased from Sigma Chemical Co. (USA). TNF- $\alpha$, IL-1 $\beta$, IL-6, IL-10 ELISA kits were purchased from Neobioscience Technology Company (China). Antibodies of COX-2, iNOS and NF-kB p65 were purchased from Boster Biotechnology Co., Ltd (China) and Beijing Bionsynthesis Biotechnology Co., Ltd (China) respectively. All other chemicals were of analytical grade and purchased locally.

\section{Preparation of the ELF}

The air dried Liquidambaris fructus were shattered to a fine powder $(2.5 \mathrm{~kg})$ and extracted with $95 \%$ ethanol $(1: 3 \mathrm{w} / \mathrm{v})$ for 1 week at room temperature three times. The filtrates were combined and concentrated under vacuum at 40 ${ }^{\circ} \mathrm{C}$ to afford $57.0 \mathrm{~g}$ of crude extract, which was then suspended in $2 \mathrm{~L}$ water and successively partitioned with ethyl acetate 3 times (2 L each). The ethyl acetate phase was dried under vacuum to yield dried powder $(32.3 \mathrm{~g})$. The dried powder was stored in a refrigerator at $4{ }^{\circ} \mathrm{C}$.

\section{Acute toxicity test}

In the acute toxicity study of ELF, Balb/c mice were randomly divided into five groups $(n=6)$ : the control group, the $0.250 \mathrm{~g} / \mathrm{kg}$ ELF group, the $0.500 \mathrm{~g} / \mathrm{kg}$ ELF group, the $1.000 \mathrm{~g} / \mathrm{kg}$ ELF group and the $2.000 \mathrm{~g} / \mathrm{kg}$ ELF group. The control group received normal saline orally. The rest groups were treated with $0.250,0.500,1.000$ and 2.000 $\mathrm{g} / \mathrm{kg}$ ELF by oral route. Mortality, general behavioral changes, neurological, signs of toxicity and hazardous symptoms of the mice were observed continuously for a period of 14 days [7].

\section{Xylene-induced mice ear swelling}

Xylene-induced mouse ear swelling test is a commonly used method to evaluate acute inflammation [8]. The mice were randomly divided into five groups $(n=8)$ and treated orally with distilled water $(10 \mathrm{~mL} / \mathrm{kg})$, ELF $(75,150$ and $300 \mathrm{mg} / \mathrm{kg}$ ) or indomethacin (10 $\mathrm{mg} / \mathrm{kg})$ respectively 30 minutes before induction of swelling by application of xylene $(0.02 \mathrm{~mL})$ to the inner surface of the left ear. 30 minutes later, the animals were sacrificed by cervical dislocation. Round pieces (diameter of $8 \mathrm{~mm}$ ) of both ears of the mice were cut off and their weights were measured. Quality difference between the left and right ear of each animal was calculated and inhibition ratio $(\mathrm{H})$ was calculated as in Eq 1 [9].

$H(\%)=\{(V c-V t / V c)\} 100$.

where $V c$ represents the weight difference between right and left ear in control groups and $V t$ represents the weight difference between right and left ear in indomethacin or ELF treated groups.

\section{Carrageenan-induced rat paw edema assay}

The in vivo anti-inflammatory activity of ELF was evaluated by the carrageenan-induced paw edema test in male Wistar rats $(180 \sim 220 \mathrm{~g})$. 
The animals were randomly divided into six groups $(\mathrm{n}=8)$. Edema was induced by injection of $100 \mu \mathrm{L}$ carrageenan $(0.1 \%$ in sterile saline) into the sub-plantar tissue of the right hind paw while the control group received the same volume of saline [10]. 60 minutes before carrageenan injection, the animals were treated with indomethacin $(10 \mathrm{mg} / \mathrm{kg})$, ELF $(50,100$ and $200 \mathrm{mg} / \mathrm{kg}$ ) or normal amount of saline by oral route. Paw thickness was measured at $0,1,2,3$, 4,5 hours after carrageenan injection using a caliper ruler and inhibition ratio was calculated as in $\mathrm{Eq} 2$. Then the rats were sacrificed after narcotized, and the blood were collected via cardiac puncture. The serum was obtained after centrifuged at $5000 \mathrm{rpm}$ for $5 \mathrm{~min}$ and then stored at $-20{ }^{\circ} \mathrm{C}$ for TNF-a, IL-6, IL-1 $\beta$ and IL-10 assay. The carrageenan induced paws were dissected, followed by stored at $-80^{\circ} \mathrm{C}$. Then the tissue lysate was prepared in RIPA for the western blot analysis of COX-2, iNOS, NF-KB p65. The tissues were also fixed in $10 \%$ buffered formalin for histological assessment.

Inhibition $(\%)=\{(V c-V t / V c)\} 100$

where $V c$ represents mean edema volume in the control group and $V t$ represents mean edema volume in groups treated with indomethacin or ELF.

\section{Measurement of serum TNF-a, IL-6, IL-1 $\beta$ and IL-10 by ELISA}

The levels of TNF-a, IL- $6, I L-1 \beta$ and IL-10 in serum were measured by ELISA kits according to the manufacturers' instructions.

\section{Histological assessment}

The paw tissues were fixed in $10 \%$ buffered formalin, dehydrated in a gradient ethanol series (70 $100 \%)$, and then embedded in paraffin. Thereafter, tissues were cut into $5 \mu \mathrm{m}$ sections, and then mounted on clean glass slides and dried overnight at $37^{\circ} \mathrm{C}$. Sections were cleared, hydrated, and stained with haematoxylin and eosin (HE) according to the manufacturers' instructions. Then the histopathological changes in all tissue sections were examined with an inverted biological microscope (XSP-18CE, Changfang, China).

\section{Western blot analysis of COX-2, iNOS and NF- KB p65}

The paw tissues were homogenized in PBS buffer $(\mathrm{pH}=7.2)$ and centrifuged at $5000 \mathrm{rpm}$ for 5 min to obtain supernatant (stored at $-20{ }^{\circ} \mathrm{C}$ ). Total protein was extracted with a RIPA solution (radio immunoprecipitation assay buffer) at $20{ }^{\circ} \mathrm{C}$ overnight. Protein from the supernatant was resolved by $12 \%$ SDS-polyacrylamide gel electrophoresis (SDS-PAGE). Then, the protein was transferred onto polyvinylidenefluoride membranes. After blocked with $5 \%$ non-fat dried milk-TBST buffer $(10 \mathrm{mM}$ Tris- $\mathrm{HCl}, \mathrm{pH} 7.4,100$ $\mathrm{mM} \mathrm{NaCl}$ and $1 \%(\mathrm{v} / \mathrm{v})$ Tween 20), the membranes were incubated with primary antibodies overnight at $4{ }^{\circ} \mathrm{C}$. Then the membranes were washed three times with TBST buffer at room temperature. After washing, the membranes were incubated with a 1: 2000 dilution of horseradish peroxidase conjugated anti-mouse IgG secondary antibody for $1 \mathrm{~h}$ at room temperature. After washing three times, the membranes were used for protein detection by enhanced chemiluminescent assay. The results were quantified by Molecular Imaging Software (Offic 600F, EPSON, Japan; Quantity One 4.62, BIO-RAD, USA).

\section{Statistical analysis}

All data are expressed as mean \pm SEM. Statistical significance was assessed by one-way analysis of variance (ANOVA), followed by Dunnet's t-test or Student-Newman-Kauls test. $P$ $<0.05$ was considered statistically significant. The analysis was performed using SPSS software, version 18.0.

\section{RESULTS}

\section{Acute toxicity of ELF}

None of the mice showed mortality or overt signs of toxicity after 14 days' treatment. The results suggest that ELF has a low toxicity profile.

\section{Effects of ELF on Xylene-induced ear swelling}

Ear swelling was obvious at $30 \mathrm{~min}$ after wipe of xylene. The data described in Table 1 showed that ELF suppressed xylene-induced ear swelling in mice with inhibition rate of $60.67 \%$ and 63.56 $\%$ at the doses of 150 and $300 \mathrm{mg} / \mathrm{kg}$ respectively. Indomethacin $(10 \mathrm{mg} / \mathrm{kg})$ also showed significant inhibitory effect.

\section{Effect of ELF on carrageenan-induced rats paw edema}

The inflammatory response of carrageenaninduced paw edema test was quantified by increment in paw thickness $0,1,2,3,4$ and $5 \mathrm{~h}$ after carrageenan injection. ELF exhibited a dose-dependent suppression of carrageenaninduced paw edema. The most obvious inhibition 
activity was exhibited at doses of $200 \mathrm{mg} / \mathrm{kg}$ (Figure 1) with the inhibition rate of $50.8 \%$ while the inhibition rate of indomethacin was $56.4 \%$.

Table 1: Effect of ELF on xylene-induced ear swelling in mice

\begin{tabular}{lccc}
\hline Group & $\begin{array}{c}\text { Dose } \\
(\mathbf{m g} / \mathbf{k g})\end{array}$ & $\begin{array}{c}\text { Ear swelling } \\
(\mathbf{m g})\end{array}$ & $\begin{array}{c}\text { Inhibition } \\
(\%)\end{array}$ \\
\hline Control & $1 \%$ CMC-Na & $6.23 \pm 0.63$ \\
& 75 & $4.02 \pm 0.52^{*}$ & 35.47 \\
ELF & 150 & $3.53 \pm 0.47^{* *}$ & 43.34 \\
& 300 & $2.45 \pm 0.39^{* * *}$ & 60.67 \\
Indo & 10 & $2.27 \pm 0.40^{* * *}$ & 63.56 \\
\hline Data are presented as mean \pm SEM $(n=8) .{ }^{*} p<0.05$, \\
${ }^{* *} p<0.01,{ }^{* * *} p<0.001$, compared with the control \\
group
\end{tabular}

Effect of ELF on serum levels of TNF-a, IL-6, IL-1 $\beta$ and IL-10

Pro-inflammatory cytokines TNF-a, IL-6, IL-1 $\beta$ and anti-inflammatory cytokine IL-10 have central roles in the process of inflammation. Therefore, levels of TNF-a, IL-6, IL-1 $\beta$ and IL-10 in serum after treatment with ELF were detected by ELISA. As shown in Figure 2, the levels of TNFa, IL-6, IL-1 $\beta$ in serum were decreased while the level of IL-10 was increased after ELF treatment in a dose-dependent manner. The results suggested that obvious inflammation response was induced in the model group (carrageenan treated group) and ELF could regulate the release of inflammatory mediators and therefor relieve the inflammatory response in carrageenan-induced rats.

\section{Effect of ELF on histopathological changes}

Immune cellular infiltration was obviously observed in the paw tissue in the model group. On the contrary, rats treated with ELF and indomethacin showed a reduction in inflammatory responses and slightly inflammatory cell infiltration (Figure 3), which demonstrated that administration of ELF directly reduce the inflammation in disease.

\section{Effect of ELF on COX-2, iNOS and NF-KB p65 expressions in paw tissue}

The expression levels of iNOS, COX-2 and NFKB p65 in the paw tissue of carrageenan-induced rats were measured by western blot analysis. The results (Figure 4) showed that expressions of COX-2 and NF-KB p65 in the model group were significantly increased compared to the control group, while the expression levels in ELF groups decreased with a dose-dependent manner compared to the model group. Meanwhile, the expression level of iNOS was increased in the model group, and ELF could decrease the expression of iNOS.

\section{DISCUSSION}

Many plants used in traditional Chinese medicine exhibit different pharmacological properties, thus they may offer potential as therapeutic agents. However, lack of scientific evidence of their mechanism of action limited the wide use of traditional Chinese medicines. The infructescence of Liquidambar formosana Hance recorded in Chinese pharmacopoeia, has been used for the treatment of various diseases such as rheumatism and inflammatory diseases [5].

Thus, in the present study we administrated ELF in vivo, and testify their potential antiinflammatory activity by xylene-induced ear swelling test and carrageenan induced rat paw edema method. The results suggested that ELF can significantly suppress the formation of xylene-induced ear swelling.
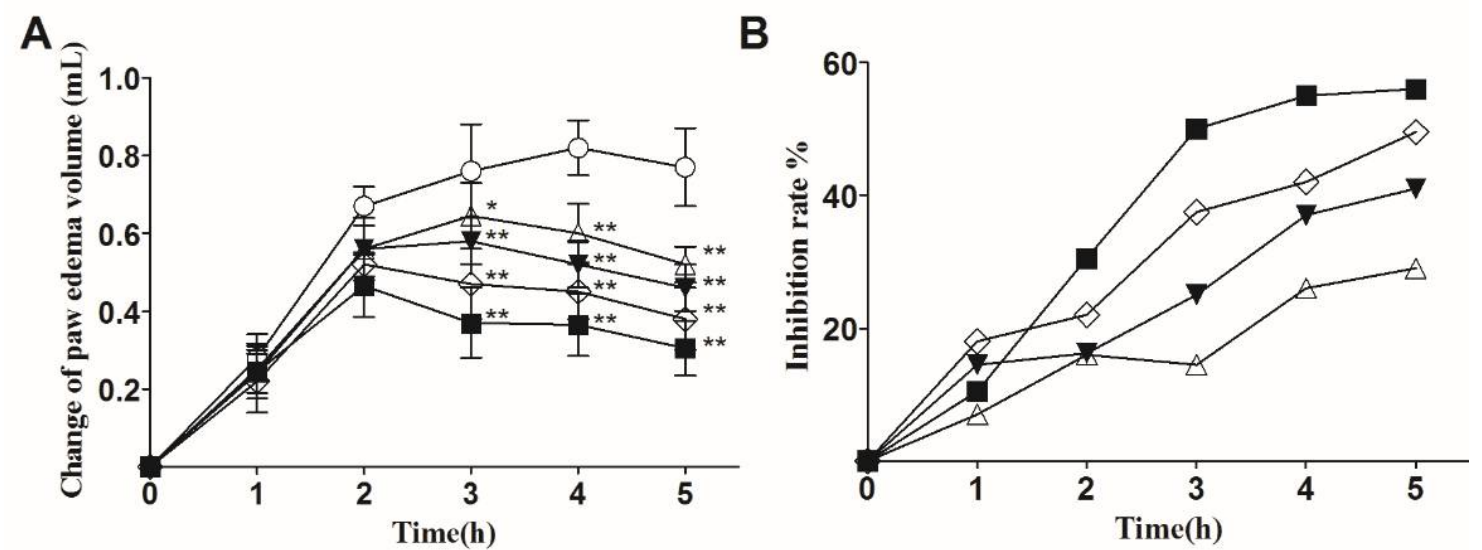

Figure 1: Effect of ELF and indomethacin on carrageenan-induced paw edema in rats. (A) change of paw edema; (B) edema inhibition rate. Data are presented as mean $\pm \operatorname{SEM}(n=8)$. ${ }^{*} p<0.05$, ${ }^{* *} p<0.01 .0$ : model group, $\mathbf{m}:$ indomethacin group, $\Delta: 50 \mathrm{mg} / \mathrm{kg}$ ELF group, $\nabla: 100 \mathrm{mg} / \mathrm{kg}$ ELF group, $\diamond: 200 \mathrm{mg} / \mathrm{kg}$ ELF group 

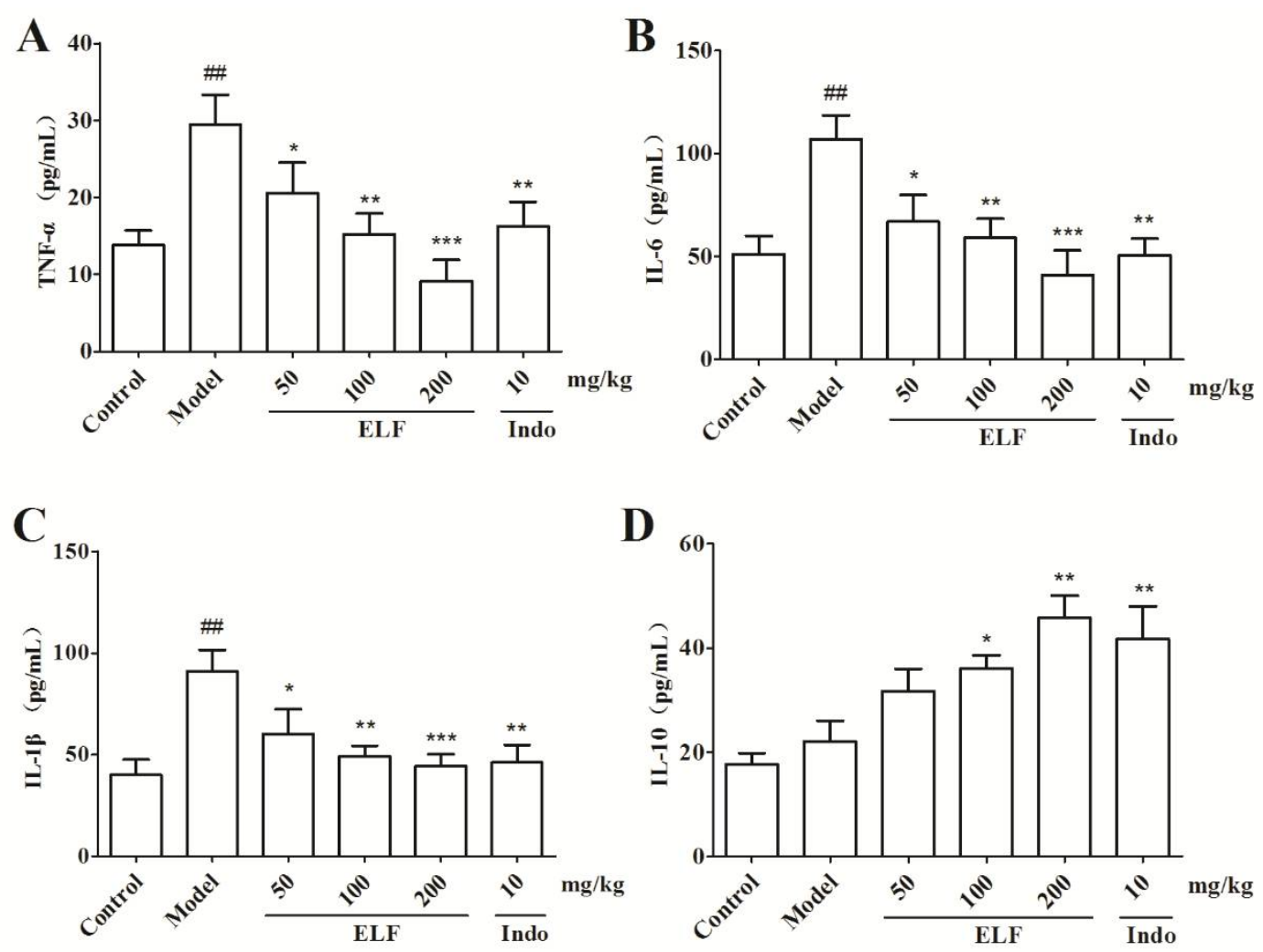

Figure 2: Effect of ELF on TNF- $\alpha(A)$, IL-6 (B), IL-1 $(C)$ and IL-10 (D) production in serum of carrageenaninduced rats. The animals were treated with different concentrations $(50,100,200 \mathrm{mg} / \mathrm{kg})$ of ELF followed by stimulation with $100 \mu \mathrm{L}$ carrageenan $\left(0.1 \%\right.$ in saline). The values are presented as mean $\pm \operatorname{SEM}(\mathrm{n}=8) ;{ }^{\# \#} p<$ 0.01 compared with control group; ${ }^{*} p<0.05,{ }^{* *} p<0.01$ and ${ }^{* \star *} p<0.001$ compared with model group
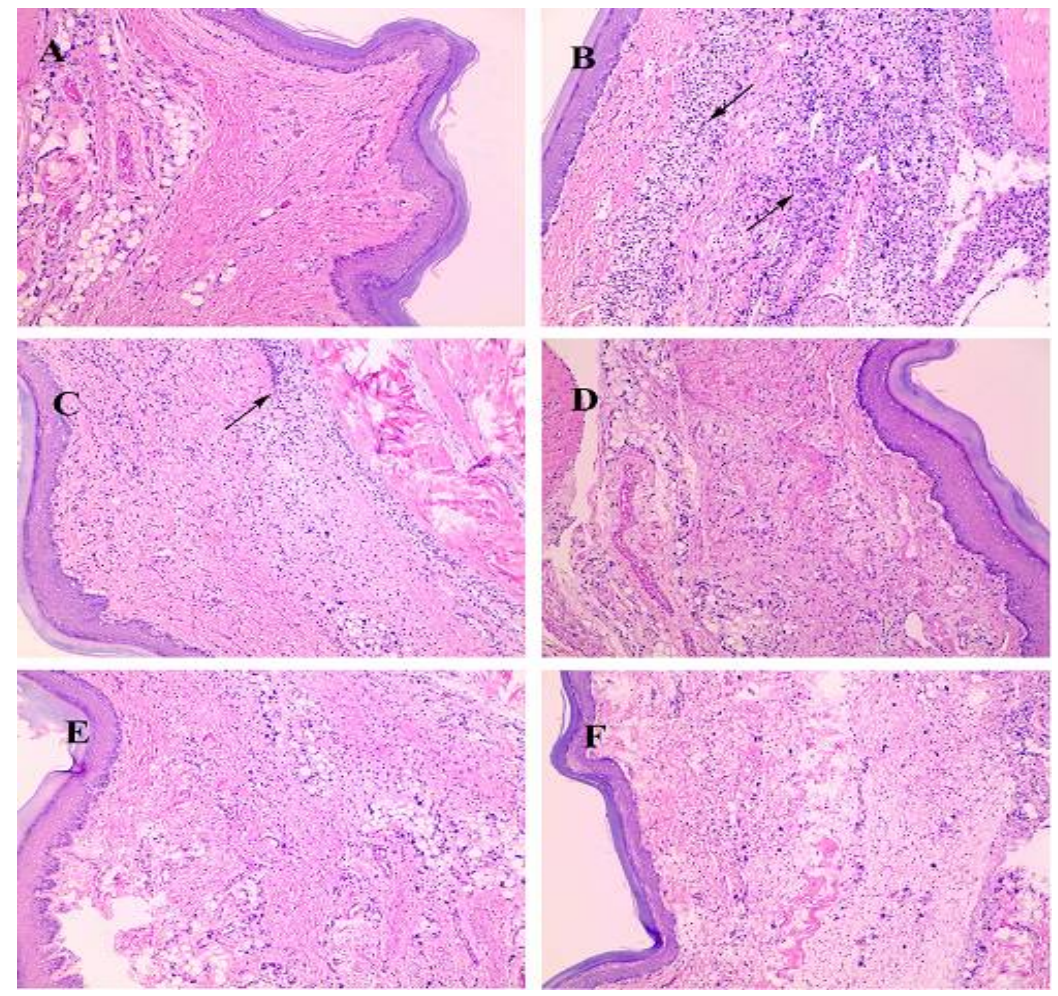

Figure 3: Histological appearance of the paws $5 \mathrm{~h}$ after injection of carrageenan $(100 \times)$. Heavy infiltration of inflammatory cells can be observed. (A): control group, (B): model group, (C): $50 \mathrm{mg} / \mathrm{kg}$ ELF group, (D): 100 $\mathrm{mg} / \mathrm{kg}$ ELF group, (E): $200 \mathrm{mg} / \mathrm{kg}$ ELF group, (F): $10 \mathrm{mg} / \mathrm{kg}$ indomethacin group 


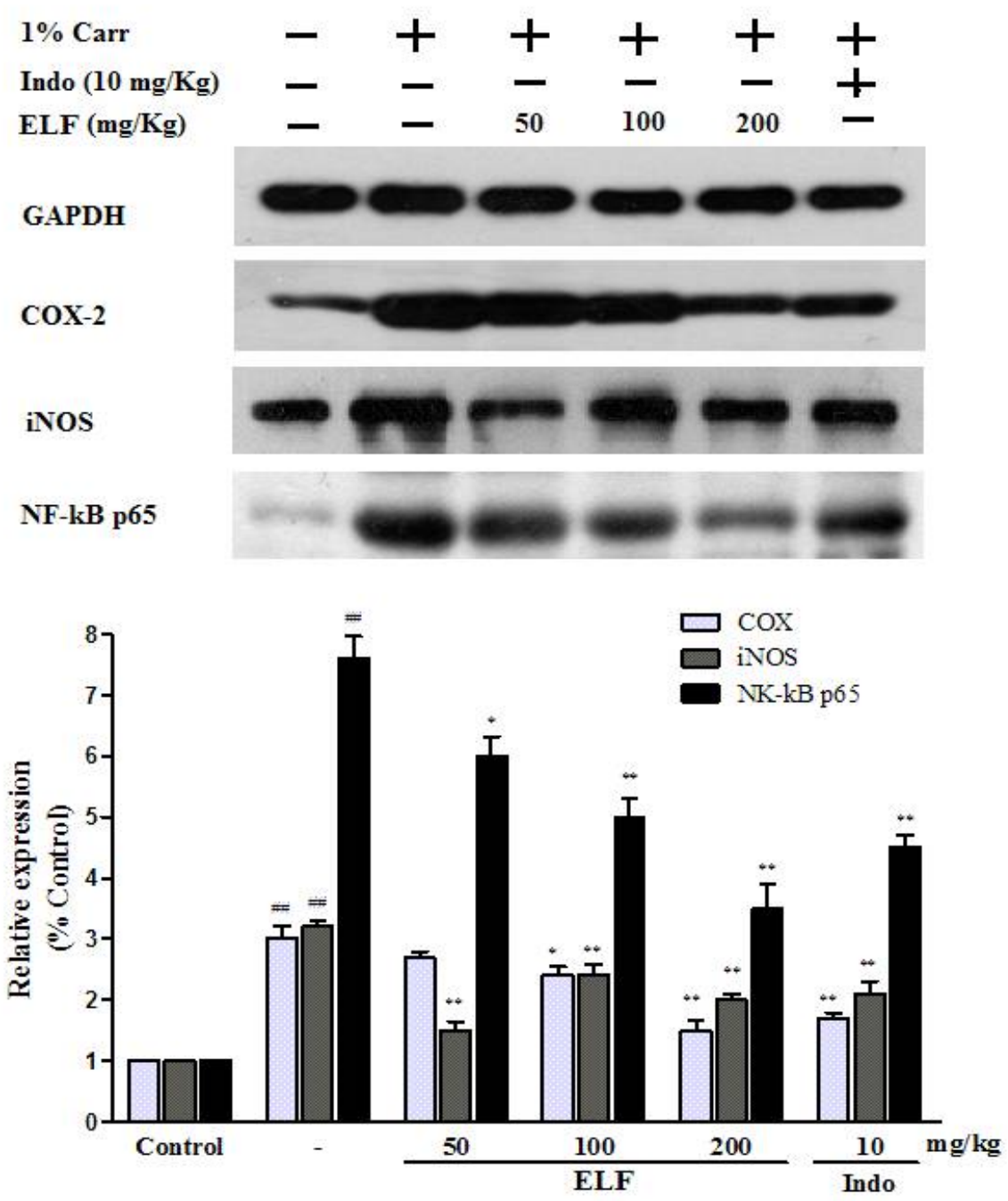

Figure 4: Effect of ELF on the expressions of iNOS, COX-2 and NF-kB p65 in carrageenan-induced paw tissue. The values are presented as means \pm SEM $(n=8) ;{ }^{\# \#} p<0.001$ compared with the control group; ${ }^{*} p<0.05$, ${ }^{* *} p<0.01$ compared with the model group

The inhibition effect of $300 \mathrm{mg} / \mathrm{kg}$ ELF was comparable to that of $10 \mathrm{mg} / \mathrm{kg}$ indomethacin. In the carrageenan-induced paw edema experiment, ELF at doses of 100 and $200 \mathrm{mg} / \mathrm{kg}$ showed a long-lasting effect of inhibition of swelling during 5 hours. The immune cell infiltration was significantly reduced in the paw tissue of the mice treated with ELF. The results indicated that ELF exhibited significant antiinflammatory activity. The anti-inflammatory activity is possibly associated with the changes of multiple inflammatory chemical mediators $[11,12]$.

A complex cytokine network is involved in inflammation process, and this network is comprised of positive and negative feedback loops that enhance or suppress the inflammatory response [13]. During the process of inflammation, the release of large amounts of the pro-inflammatory cytokines, such as IL-1 $\beta$, IL-6 and TNF- $\alpha$, could lead to the aggravation of inflammatory diseases $[14,15]$. On the contrary, anti-inflammatory cytokines such as IL-10 have been shown to inhibit expressions of proinflammatory cytokines [16]. Previous reports have demonstrated that IL-10 could suppress the inflammatory cytokines IL-1, TNF- $\alpha$, IL- 6 , IL-8, and IL-12, as well as inhibit the synthesis of nitric oxide, gelatinase, and collagenase [17]. Therefore, increased IL-10 and inhibition of proinflammatory cytokines have been proposed to be a useful approach to treat inflammatory diseases [18]. In the present study, the antiinflammatory effect of ELF in the carrageenaninduced paw edema experiment appears to result from the regulation of key cytokines in inflammatory pathogenesis, such as decreasing the levels of TNF- $\alpha, I L-6, I L-1 \beta$ and increasing the level of IL-10 in serum.

$\mathrm{NF}-\mathrm{KB}$ is a critical factor for the expression of various pro-inflammatory cytokines, such as TNF- $\alpha$, IL- 6 and IL-1 $\beta$ [19]. Suppression of NF- 
$\mathrm{KB}$ can lead to the reduction of pro-inflammatory cytokines, thus modulate the inflammatory process. Inflammation mediator NO is produced by iNOS and involved in many biological functions. Overexpression of iNOS is associated with inflammatory responses and serious disorders such as septic shock and rheumatoid arthritis [20]. Our study showed that the levels of COX-2, iNOS and NF-KB p65 expressions were significantly decreased in ELF and indomethacin treated groups. Moreover, the expressions of NFKB p65 and COX-2 were down-regulated in a dose-dependent manner.

\section{CONCLUSION}

The findings indiate that ELF exhibits antiinflammatory activity in xylene-induced mice ear swelling test and carrageenan-induced rat paw edema experiment, and ELF can regulate the levels of TNF- $\alpha$, IL- $1 \beta$, IL- 6 and IL-10 in serum of carrageenan treated rats. The anti-inflammatory effect is associated with suppression of NF-KB p65, iNOS and COX-2. These results may suggest that ELF may be useful in the treatment to treat inflammatory disease in future.

\section{DECLARATIONS}

\section{Acknowledgement}

This work was financially supported by program for Applied Basic Research Programs of Science and Technology Department of Hubei Province (no. 2015061701011620) and National Natural Science Foundation of China (no. 31400298).

\section{Conflict of Interest}

No conflict of interest associated with this work.

\section{Contribution of Authors}

The authors declare that this work was done by the authors named in this article and all liabilities pertaining to claims relating to the content of this article will be borne by them.

\section{Open Access}

This is an Open Access article that uses a funding model which does not charge readers or their institutions for access and distributed under the terms of the Creative Commons Attribution License (http://creativecommons.org/licenses/by/ 4.0) and the Budapest Open Access Initiative (http://www.budapestopenaccessinitiative.org/rea d), which permit unrestricted use, distribution, and reproduction in any medium, provided the original work is properly credited.

\section{REFERENCES}

1. Mantovani A, Allavena $P$, Sica A, Balkwill F. Cancerrelated inflammation. Nature 2008; 454(7203): 436-444.

2. Fangkrathok $N$, Junlatat J, Sripanidkulchai $B$. In vivo and in vitro anti-inflammatory activity of Lentinus polychrous extract. J Ethnopharmacol. 2013; 147(3): 631-637.

3. Laskin DL, Pendino KJ. Macrophages and inflammatory mediators in tissue injury. Annu Rev Pharmacol Toxicol. 1995; 35: 655-677.

4. O'Dell JR. Therapeutic strategies for rheumatoid arthritis. N Engl J Med. 2004; 350(25): 2591-2602.

5. Commission Pharmacopoeia Commission. Pharmacopoeia of the People's Republic of China (2010 English Edition). Beijing: China Medical Science Press; 2010.

6. Howard-Jones N. A CIOMS ethical code for animal experimentation. WHO chronicle 1985; 39(2): 51-56.

7. Mondal A, Rajalingam D, Kumar Maity T. Antiinflammatory effect of O-methylated flavonol 2-(3,4dihydroxy-phenyl)-3,5-dihydroxy-7-methoxy-chromen-4one obtained from Cassia sophera Linn in rats. $J$ Ethnopharmacol. 2013; 147(2): 525-529.

8. Xu SY, Bian RL, Chen X. Experimental methodology of pharmacology. Beijing: People's Medical Publishment House; 2002.

9. Kou J, Sun $Y$, Lin $Y$, Cheng $Z$, Zheng $W, Y u B, X u Q$. Anti-inflammatory activities of aqueous extract from Radix Ophiopogon japonicus and its two constituents. Biol Pharm Bull. 2005; 28(7): 1234-1238.

10. Sripanidkulchai B, Junlatat J, Wara-aswapati N, Hormdee D. Anti-inflammatory effect of Streblus asper leaf extract in rats and its modulation on inflammation-associated genes expression in RAW 264.7 macrophage cells. $J$ Ethnopharmacol. 2009; 124(3): 566-570.

11. Csermely $P$, Agoston V, Pongor $S$. The efficiency of multi-target drugs: the network approach might help drug design. Trends Pharmacol Sci. 2005; 26(4): 178182.

12. Zhu YP, Woerdenbag HJ. Traditional Chinese herbal medicine. Pharm World Sci. 1995; 17(4): 103-112.

13. Feldmann M, Brennan FM, Maini RN. Role of cytokines in rheumatoid arthritis. Annu Rev Immunol. 1996; 14: 397440.

14. Glauser MP. The inflammatory cytokines. New developments in the pathophysiology and treatment of septic shock. Drugs 1996; 52 Suppl 2: 9-17.

15. Mannel DN, Echtenacher $B$. TNF in the inflammatory response. Chem Immunol. 2000; 74: 141-161.

16. Fiorentino DF, Zlotnik A, Mosmann TR, Howard M, O'Garra A. IL-10 inhibits cytokine production by activated macrophages. J Immunol. 1991; 147(11): 3815-3822.

17. Chernoff AE, Granowitz EV, Shapiro L, Vannier E, Lonnemann G, Angel JB, Kennedy JS, Rabson AR, 
Wolff SM, Dinarello CA. A randomized, controlled trial of IL-10 in humans. Inhibition of inflammatory cytokine production and immune responses. J Immunol. 1995; 154(10): 5492-5499.

18. Kawanishi $S$, Hiraku $Y$, Pinlaor S, Ma N. Oxidative and nitrative DNA damage in animals and patients with inflammatory diseases in relation to inflammation-related carcinogenesis. Biol Chem. 2006; 387(4): 365-372.
19. Li Q, Verma IM. NF-kappaB regulation in the immune system. Nat Rev Immunol. 2002; 2(10): 725-734.

20. Chiu CS, Deng JS, Chang HY, Chen YC, Lee MM, Hou WC, Lee CY, Huang SS, Huang GJ. Antioxidant and anti-inflammatory properties of Taiwanese yam (Dioscorea japonica Thunb. var. pseudojaponica (Hayata) Yamam.) and its reference compounds. Food Chem. 2013; 141(2): 1087-1096. 